\title{
AUTOMATION TESTING TOOL DALAM PENGUJIAN APLIKASI BELAJAR TAJWID PADA PLATFORM ANDROID
}

\author{
Herlinda $^{1}$, Dona Katarina ${ }^{2}$, Erlin Windia Ambarsari ${ }^{3}$ \\ Informatika, Universitas Indraprasta PGRI \\ linda_said72@ymail.com ${ }^{1}$, donakatarina@yahoo.com ${ }^{2}$, erlinunindra@gmail.com ${ }^{3}$
}

Submitted November 27, 2019; Revised November 30, 2019; Accepted Desember 1, 209

\begin{abstract}
Abstrak
Tidak seperti pada Black Box Testing yang biasanya dilakukan secara manual, maka di dalam penelitian ini menggunakan automation testing tool, yaitu Katalon. Katalon digunakan untuk pengujian dengan menggunakan test case. Test case ini dilakukan dengan cara melakukan record dan playback, berarti perlu merekam setiap respon dalam satu event pada aplikasi yang digunakan. Tujuannya adalah untuk menganalisis efektivitas aplikasi yang sudah dibangun, yang kemudian apakah Automation Testing Tool Katalon berdaya guna dibandingkan pengujian manual. Oleh karena itu, akan dapat diketahui kekurangan dari penggunaan Katalon terutama pada aplikasi Android. Langkah-langkah yang dilakukan dalam pengujian aplikasi tajwid adalah Merekam test case dengan perangkat mobile, mengkonfigurasi dan merekam langkah pengujian mobile, menjalankan hasil test case, dan melihat log eksekusi. Dari penelitian didapatkan terjadi tiga kesalahan didalam aplikasi, diantaranya ketidaksesuai ukuran layar dalam mode landscape, terdapatnya kegagalan eksekusi dikarenakan Katalon tidak dapat mendeteksi objek yang tidak masuk dalam tangkap layar Device View, dan objek suara yang tidak berhenti jika sudah pindah halaman layar.
\end{abstract}

Kata Kunci: Black Box Testing, Katalon, Android, Test Case

\begin{abstract}
Dissimilar in Black Box Testing, which is usually manually, this research uses an automation testing tool, namely Katalon. The Katalon used for testing using a test case. A test case by recording and playback; it needs to record every response in one event in the application used. The aim is to analyze the effectiveness software that has built and whether the Katalon Automation Testing Tool is efficient if compared to manual testing. Therefore, it is known the shortcomings of the use of Katalon, especially on Android applications. The steps taken in testing the Tajweed application are recording the test case with a mobile device, configuring and documenting the actions of the portable test, running the results of the test case, and viewing the execution log. The research found three errors that occurred in the application. There is the screen size mismatch in landscape mode, a failure of execution because the Katalon could not detect objects that were not captured by the Device View and sound objects that did not stop if the screen page had switched over.
\end{abstract}

Key Words: Black Box Testing, Katalon, Android, Test Case

\section{PENDAHULUAN}

Pada era industri 4.0, aplikasi mobile sudah banyak mendomisili business intelligent yang dilakukan oleh para startup sebagai pengembang dengan memanfaatkan platform Android dan IOS. Contohnya seperti bukalapak, tokopedia, gojek, dan traveloka yang berbasis mobile dengan mengembangkan Artificial Intelligent untuk memahami keinginan user sebagai pelanggannya. Ditambah pula dengan berjamurnya Fintech P2P Lending yang memanfaatkan teknologi tersebut, menelusuri bagaimana perilaku calon kreditur untuk menentukan penerimaan pengajuan kredit. 
Belum lagi popularnya e-sport seperti PUBG, Mobile Legends, Dota 2, Pro Evaluation Soccer (PES), Arena of Valor, dan Clash Royale yang dipertandingkan di SEA Games, ASIAN Games, dan turnamen lainnya. Dengan kata lain, end user diberi kemudahan dengan dimanjakan oleh ragamnya aplikasi. Namun, perlu diperhatikan pula untuk mengembangkan aplikasi berbasis Android, sudah pasti masalah bug tidak dapat dihindarkan. Kesalahan terjadi pada perangkat lunak yang disebabkan karena tidak sesuai dengan kebutuhan perangkat lunak [1], sehingga perlu dilakukan perbaikan.

Ketika perbaikan bug, dilakukan pengujian seperti memeriksa setiap fitur yang digunakan oleh aplikasi. Metode-metode yang digunakan dalam pengujian dapat dilakukan dengan Black Box Testing. Berdasarkan pada penelitian dari [2] bahwa Black Box Testing tidak memerlukan pengujian desain maupun kode program, melainkan hanya fokus terhadap fungsinya saja sesuai dengan spesifikasi yang dibutuhkan. Pengujian Black Box Testing, dapat dilakukan dengan manual dan otomatis. Menurut [3], pengujian secara manual tidak efektif. Perlu juga dilakukan dengan pengujian otomatis.

Berdasarkan pernyataan dari [4], yang dimana secara umumnya pengujian manual merupakan aktivitas sistematik dan mengikuti proses. Proses tersebut melibatkan para pakar untuk menganalisis kebutuhan, dengan mempersiapkan rencana pengujian, mengatur lingkungan pengujian, mengidentifikasi skenario pengujian, mempersiapkan pengujian kasus dan data, pengujian eksekusi, dan laporan cacat. Namun, pengujian ini tidak efisien jika dilakukan pengujian regresi (berulang-ulang). Misalkan pada penelitian dari [5] memerlukan 16 orang anggota BRIMOB untuk melakukan validasi dalam pengujian aplikasi Action \& Strategy. Sedangkan pada pengujian otomatis tidak melibatkan pakar untuk validasi dan dapat mengendalikan pengujian eksekusi dengan kemampuan menjalankan banyak pengujian dengan waktu singkat, kompatibiltas yang berarti dapat menjalankan di lingkungan berbeda. Selain itu, pengujian otomatis dapat mempercepat pengujian unit, pengujian API, dan pengujian GUI.

Oleh karena itu, pada penelitian ini dilakukan menggunakan pengujian otomatis. Alat yang digunakan dalam pengujian otomatis atau disebut dengan Automation Testing Tool, yaitu Katalon. Dalam penelitian [6], Katalon digunakan untuk pengujian e-commerce. Sampel yang diambil adalah Tokopedia, JD. ID, dan Bukalapak, dengan menggunakan test case. Test case ini dilakukan dengan cara melakukan record dan playback, berarti perlu merekam setiap respon dalam satu event pada e-commerce yang dilakukan pengguna.

Pengujian dengan menggunakan Katalon pada penelitian ini, dilakukan kepada aplikasi dengan platform Android. Sampel yang digunakan adalah aplikasi Tajwid yang dibangun oleh [7] dengan melakukan test case. Tujuannya adalah untuk menganalisis efektivitas aplikasi yang sudah dibangun, yang kemudian apakah Automation Testing Tool Katalon berdaya guna dibandingkan pengujian manual. Oleh karena itu, akan dapat diketahui kekurangan dari penggunaan Katalon terutama pada aplikasi Android.

\section{METODE PENELITIAN}

Katalon yang dikembangkan oleh Katalon LLC bertujuan sebagai pemberi solusi otomatis yang terjangkau, karena berbasis open source dan dibuat sesimpel mungkin, sehingga dengan dibangunnya Katalon Studio dapat membantu QA (Software Quality Assurance) baik untuk QA pemula maupun profesional untuk melakukan pengujian dengan mudah. Pengujian pada 
Katalon mencakup Web UI, API, Mobile dan Scripting. Berbeda yang dilakukan oleh [6], dimana dapat langsung menggunakan Katalon dalam pengujiannya karena pengujian dilakukan adalah GUI halaman web. Pada penelitian ini, pengujian yang dilakukan adalah pengujian aplikasi berbasis Android (Mobile), sehingga perlu dilakukan setup terlebih dahulu. Sesuai pada pedoman dari [8], alatalat yang digunakan untuk setup adalah sebagai berikut:

1) Node.js

Node.js dibangun sebagai aplikasi berbasis web dan ditulis dalam sintaks Javascript. Node.js digunakan untuk melengkapi peran JavaScript (an asynchronous event-driven JavaScript runtime) sehingga bisa berjalan di sisi server. Bahkan untuk dijalankan tanpa menggunakan program server web, dikarenakan mempunyai pustaka server HTTP sendiri.

2) Appium

Appium digunakan sebagai alat otomatisasi untuk aplikasi native (asli), mobile web, ataupun hybrid untuk platform iOS serta android. Appium dapat dijalankan pada simulator ataupun perangkat asli (smartphone) yang berbasis open source.

3) Perangkat Asli

Katalon memerlukan Operating System version yang terdapat dalam iOS atau Android. Oleh karena itu, Smartphone yang digunakan sudah terdapat instalan USB driver dan terdeteksi melalui opsi pengembang (Gambar 1) dengan mengkonfigurasi Debugging USB didalam smartphone (fitur opsi pengembang berbeda-beda, tergantung dari smarphone yang digunakan). Hasil konfigurasi dari opsi pengembang tersebut, membuat smartphone terkoneksi pada Katalon yang dapat dilihat pada Gambar 2.
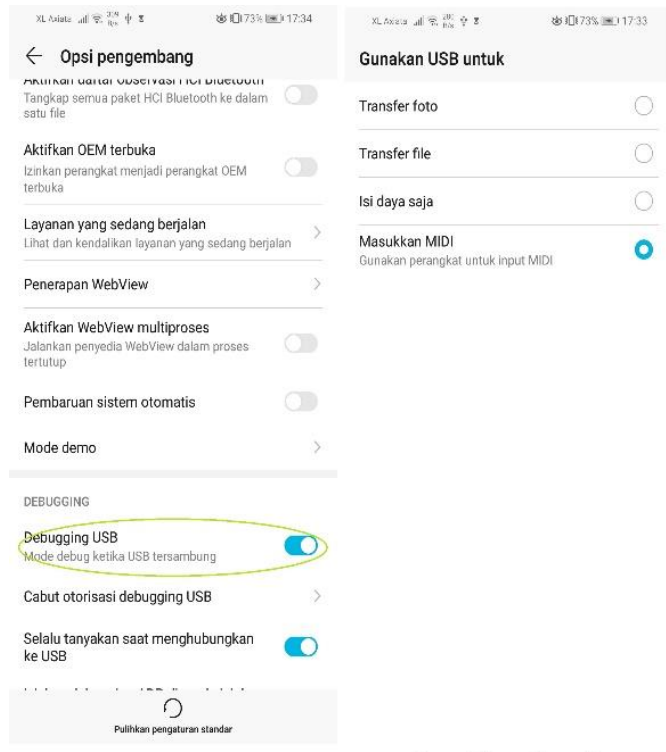

Sumber : Dokumen Pribadi

Gambar 1. Konfigurasi Pada Opsi Pengembang

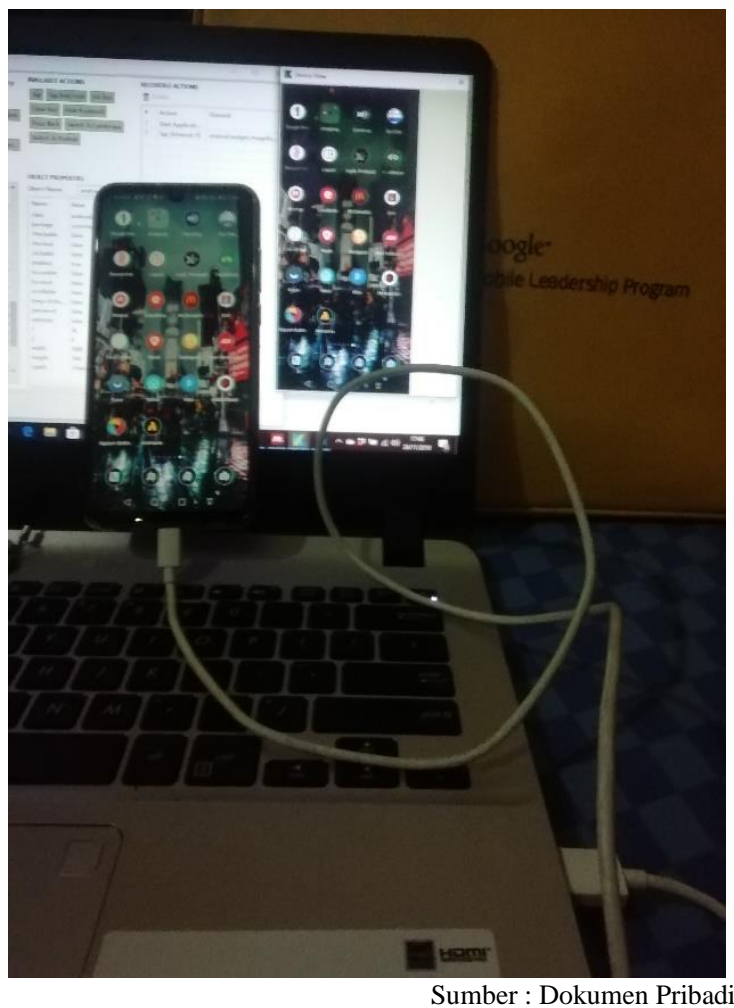

Gambar 2. Koneksi Smartphone dengan Katalon dari Konfigurasi Gambar 1.

Setelah dilakukan setup alat-alat untuk pengujian Android, maka yang dilakukan adalah melakukan pengujian test case pada aplikasi Tajwid dengan mengikuti langkahlangkah sebagai berikut: 
1) Merekam Mobile Utility[9]

Merekam atau record tidak dapat dilakukan jika belum melakukan konfigurasi terlebih dahulu, poin penting yang dilakukan dalam konfigurasi antara lain:

Tabel 1. Konfigurasi Rekaman Mobile

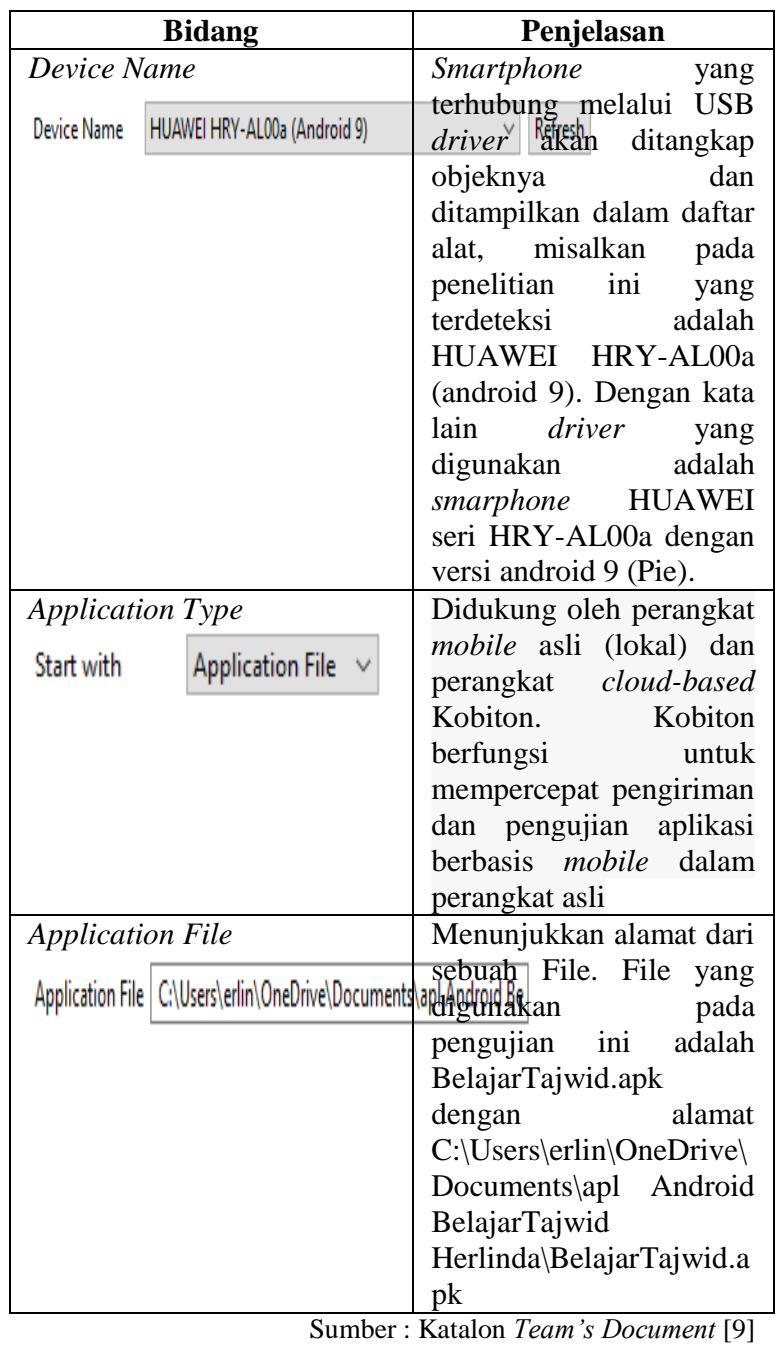

Kemudian memulai perekaman dengan menekan tombol Start, Katalon akan mengaktifkan Appium dan ditransfer ke dalam smartphone sehingga Android dapat berinteraksi dengan beberapa sistem API. Setelah itu, Katalon menangkap semua objek yang ada dalam aplikasi Tajwid dan tersimpan pada All Objects dalam bentuk hirarki. Jika memilih elemen objek apapun pada hirarki dalam All Objets, maka akan tersorot didalam
Device View. Device View berfungsi sebagai penangkap layar aplikasi dari smartphone yang digunakan.

Setelah memilih elemen objek, dapat dilakukan eksekusi setiap fitur yang digunakan dalam aplikasi dengan memilih setiap action pada Available Actions.

2) Mengeksekusi test case yang sudah digeneralisasi di salah satu perangkat yang didukung yaitu HUAWEI HRYAL00a (android 9).

\section{HASIL DAN PEMBAHASAN}

Berdasarkan penjelasan sebelumnya mengenai Available Actions, yang mempunyai fungsi sebagai eksekusi setiap action dimana merupakan tombol-tombol fitur aplikasi tajwid yang nantinya akan disimpan kedalam Recorded Actions seperti pada gambar dibawah ini.

\section{RECORDED ACTIONS}

Delete

\begin{tabular}{|l|l|l|}
\hline \# & Action & Element \\
\hline 1 & Start Applicati... & \\
\hline 2 & Switch To Lan... & \\
\hline 3 & Switch To Port... & \\
\hline 4 & Tap [timeout: 0] & android.widget.ImageBu... \\
\hline 5 & Press Back & \\
\hline 6 & Tap [timeout: 0] & android.widget.ImageBu... \\
\hline 7 & Tap [timeout: 0] & android.widget.ImageBu... \\
\hline 8 & Press Back & \\
\hline 9 & Tap [timeout: 0] & android.widget.ImageBu... \\
\hline 10 & Press Back & \\
\hline 11 & Tap [timeout: 0] & android.widget.ImageBu... \\
\hline 12 & Press Back & \\
\hline 13 & Tap [timeout: 0] & android.widget.ImageBu... \\
\hline 14 & Press Back & \\
\hline 15 & Press Back & \\
\hline 16 & Tap [timeout: 0] & android.widget.ImageBu... \\
\hline & & \\
\hline
\end{tabular}

Gambar 3. Recorded Actions Aplikasi Tajwid

Recorded Action sebagai dasar analisa pengujian dalam bentuk script testing yang diambil dari hasil rekaman mobile utility dan eksekusi test case. 

Mobile.startApplication('C: $\backslash \backslash$ Users $\backslash$ lerlin $\backslash \backslash$ OneDrive $\backslash D$
ocuments $\backslash$ lapl $\quad$ Android Herlinda\BelajarTajwid.apk',

true)

Mobile.switchToLandscape()

Mobile.switchToPortrait()

Mobile.tap(findTestObject('TajwidCap/android.widget. ImageButtonO $\left.\left.(65)^{\prime}\right), 0\right)$

Mobile.pressBack()

Mobile.tap(findTestObject('TajwidCap/android.widget ImageButton0 (66)'), 0)

Mobile.tap(findTestObject('TajwidCap/android.widget. ImageButtonO (67)'), 0)

Mobile.pressBack()

Mobile.tap(findTestObject('TajwidCap/android.widget. ImageButtonO (68)'), 0)

Mobile.pressBack()

Mobile.tap(findTestObject('TajwidCap/android.widget. ImageButtonO (69)'), 0)

Mobile.pressBack()

Berdasarkan dari eksekusi tersebut, dilakukan Job Progress untuk menganalisa response time pada setiap objek didalam aplikasi tajwid. Response time tersebut tergantung dari respon smartphone saat membuka setiap objek sehingga jika $J o b$ Progress dilakukan berulang, maka hasil response timepun akan berbeda dari response time sebelumnya. Responsif dari aplikasi tajwid dapat dilihat pada Log Viewer seperti gambar berikut:

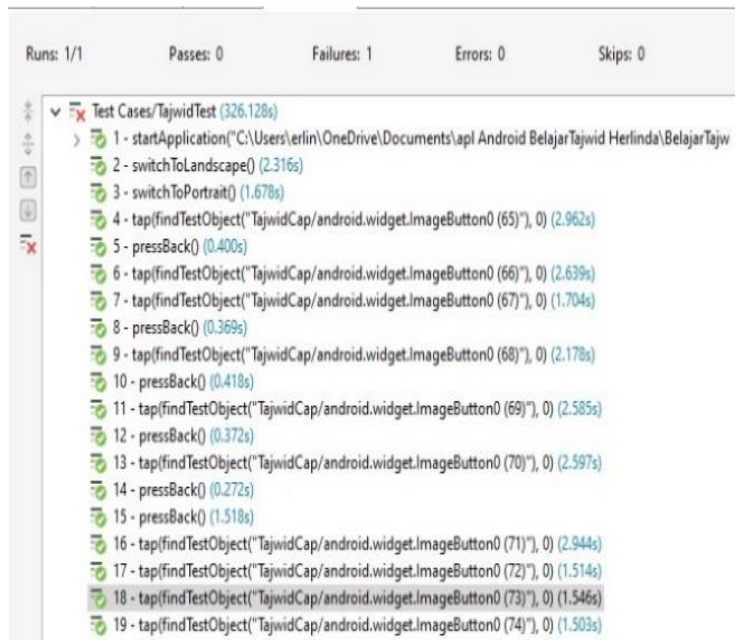

Gambar 4. Log Viewer aplikasi tajwid
Pada aplikasi tajwid membutuhkan 326,128 detik atau rata-rata sekitar 26,128 detik sampai dengan 5 menit untuk setiap objek didalam aplikasi. Pengujiannya pun membutuhkan sekitar 121 langkah dari mulai membuka aplikasi sampai ditutup kembali.

Diantara 121 langkah tersebut terdapat objek yang paling penting untuk dianalisa pengujiannya, yaitu pada fitur-fitur di dalam aplikasi tajwid dimana lebih banyak menggunakan template dan tidak membutuhkan database. Objek-objek yang dianalisa diantaranya adalah:

1) Fitur About, yang merupakan informasi dari aplikasi tajwid.

2) Fitur Mahraj, merupakan ilustrasi tempat keluarnya huruf. Mahraj terdiri dari objek Mahraj Rongga Mulut, Mahraj Tenggorokan, Mahraj Lidah, dan Mahraj Bibir

3) Fitur Tajwid, merupakan bagaimana cara mengucapkan huruf-huruf yang terdapat dalam Al-Quran maupun bukan. Tajwid sendiri terdiri dari objek Tanwin (Izhar. Idgham, Ikhfa, Iqlab), Mim Mati (Ikhfa Syafawi, Idgham Mislain, Izhar Syafawi), Hukum Mad (Mad Thobi'i, Mad Wajib Muttasii, Mad Jaiz Munfasil, Mad Arid Lisukun), Hukum Idgham (Idgham Mutamatsilain, Idgham Mutajanisain, Idgham Mutaqaribain), dan Qalqalah (Qalqalah Kubro, Qalqalah Sugro). Ilustrasi Tajwid lebih sulit jika hanya berupa tulisan. Oleh karena itu, untuk mempermudah mendemontrasikan objek-objek di dalam tajwid, maka dari masingmasing objek tersebut disematkan objek tombol suara.

4) Fitur Kuis; yang terdiri 18 pertanyaan, masing-masing pertanyaan terdiri dari objek pilih (radio button) dan objek tombol btnsubmit untuk eksekusi jawaban dari pertanyaan yang diajukan. 


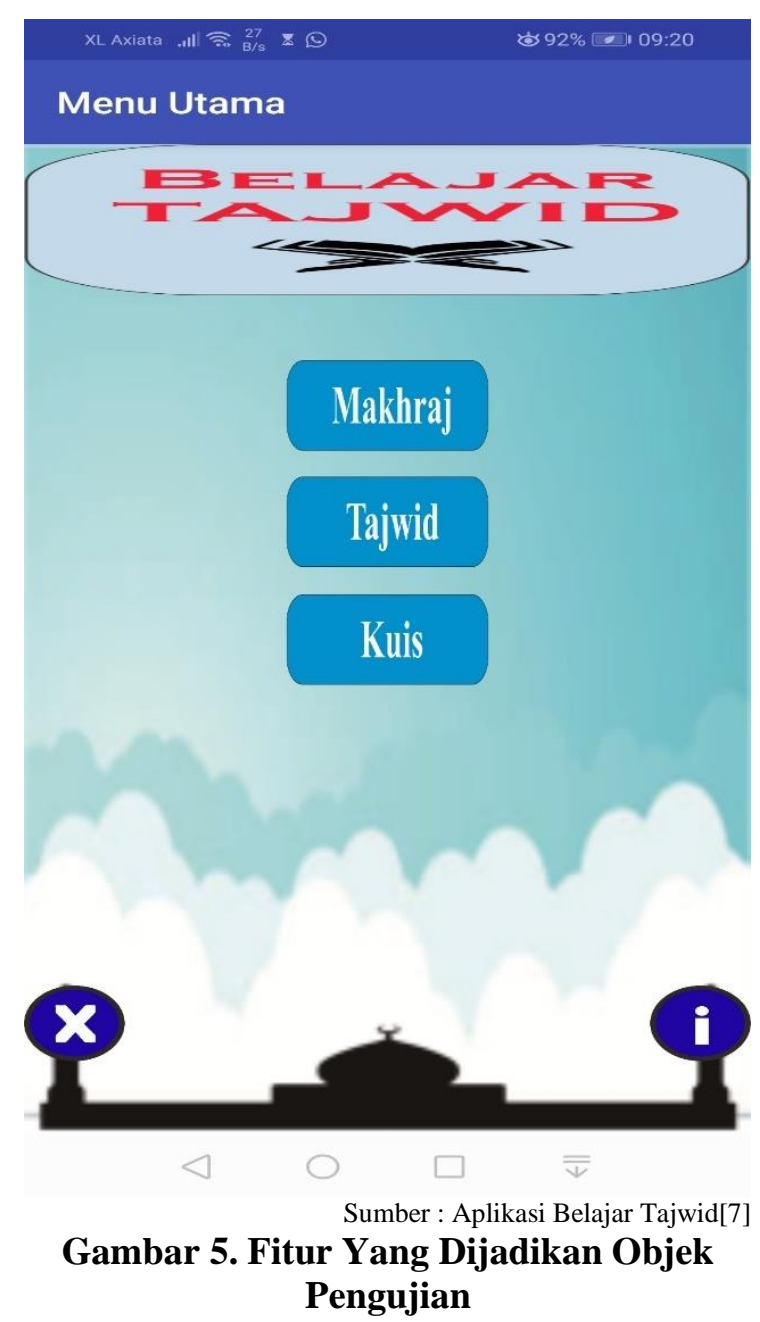

Berikut adalah beberapa response time dari objek-objek aplikasi tajwid yang diambil dalam test case.

Tabel 2. Response Time Aplikasi Tajwid

\begin{tabular}{|c|c|c|c|}
\hline No & Objek Utama & $\begin{array}{l}\text { Respon } \\
\text { se Time } \\
\text { (detik) }\end{array}$ & Keterangan \\
\hline 1 & $\begin{array}{l}\text { Menjalankan } \\
\text { Aplikasi } \\
\text { Rubah tampilan } \\
\text { layar ke }\end{array}$ & 32,068 & $\begin{array}{l}\text { Aplikasi } \\
\text { BelajarTajwid.apk } \\
\text { Sukses, tetapi } \\
\text { tampilan melebihi }\end{array}$ \\
\hline 2 & Landscape & 2,316 & layar \\
\hline 3 & About & 2,962 & Sukses \\
\hline 4 & Mahraj & 2,639 & Sukses \\
\hline 5 & $\begin{array}{l}\text { Mahraj/ronggam } \\
\text { ulut } \\
\text { Mahraj/tenggoro }\end{array}$ & 1,704 & Sukses \\
\hline 6 & kan & 2,178 & Sukses \\
\hline 7 & Mahraj/lidah & 2,585 & Sukses \\
\hline 8 & mahraj/bibir & 2,597 & Sukses \\
\hline 9 & Tajwid & 2,944 & Sukses \\
\hline 10 & tajwid/tanwin & 1,514 & Sukses \\
\hline
\end{tabular}

\begin{tabular}{|c|c|c|c|}
\hline 11 & $\begin{array}{l}\text { tajwid/tanwin/iz } \\
\text { har }\end{array}$ & 1,546 & Sukses \\
\hline 12 & $\begin{array}{l}\text { tajwid/tanwin/iz } \\
\text { har-suara } \\
\text { taiwid/tanwin/id }\end{array}$ & 1,503 & Sukses \\
\hline 13 & $\begin{array}{l}\text { ghm } \\
\text { taiwid/tanwin/id }\end{array}$ & 3,067 & Sukses \\
\hline 14 & $\begin{array}{l}\text { ghm-suara1 } \\
\text { tajwid/tanwin/id }\end{array}$ & 31,971 & $\begin{array}{l}\text { ditemukan } \\
\text { Gagal, Tidak }\end{array}$ \\
\hline 15 & $\begin{array}{l}\text { ghm-suara2 } \\
\text { tajwid/tanwin/ik }\end{array}$ & 31,286 & ditemukan \\
\hline 16 & $\begin{array}{l}\text { hfa } \\
\text { tajwid/tanwin/ik }\end{array}$ & 2,5 & Sukses \\
\hline 17 & $\begin{array}{l}\text { hfa-suara } \\
\text { tajwid/tanwin/iq }\end{array}$ & 33,027 & Sukses \\
\hline 18 & $\begin{array}{l}\text { lab } \\
\text { tajwid/tanwin/iq }\end{array}$ & 2,605 & Sukses \\
\hline 19 & lab-suara & 2,991 & Sukses \\
\hline 20 & $\begin{array}{l}\text { tajwid/mimmati } \\
\text { tajwid/mimmati/ }\end{array}$ & 3,136 & Sukses \\
\hline 21 & $\begin{array}{l}\text { syafawi } \\
\text { tajwid/mimmati/ }\end{array}$ & 1,442 & Sukses \\
\hline 22 & $\begin{array}{l}\text { syafawi-suara } \\
\text { tajwid/mimmati/ }\end{array}$ & 3,5 & Sukses \\
\hline 23 & $\begin{array}{l}\text { mislain } \\
\text { tajwid/mimmati/ }\end{array}$ & 2,294 & Sukses \\
\hline 24 & mislain-suara & 1,478 & Sukses \\
\hline
\end{tabular}

Berdasarkan Tabel 2, didapatkan beberapa kesalahan dari aplikasi tajwid yang diantaranya adalah tampilan layar tidak dapat menyesuaikan ketika dirubah ke dalam mode Landscape. Sehingga mengakibatkan tampilan aplikasi keluar dari tampilan layar smartphone. Oleh karena itu, perlu dilakukan pengaturan mode screen agar tetap dalam layar portrait.

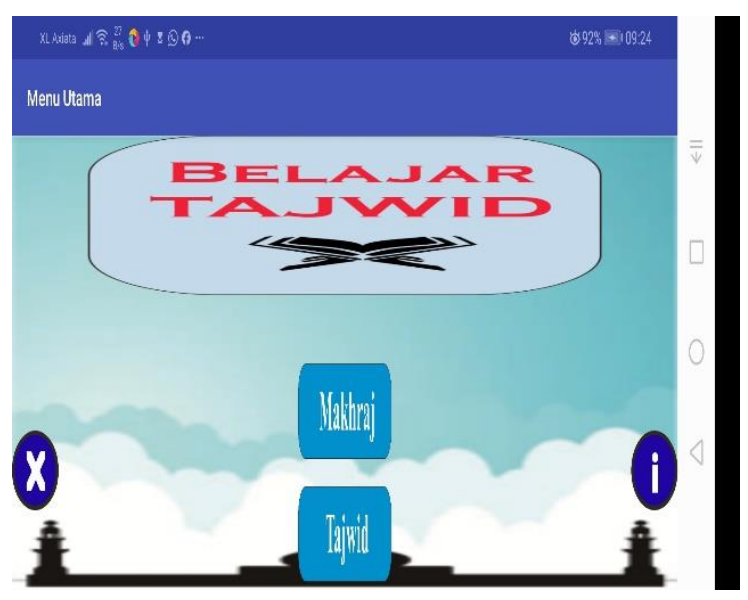

Gambar 6. Tampilan Layar Dalam Bentuk Mode Landscape 
Kemudian terjadi kegagalan pada saat menjalankan sistem, yaitu pada no. 14 tajwid/tanwin/idghm-suara1 dan 15 tajwid/tanwin/idghm-suara2. Hal ini terjadi dikarenakan response time lebih lama yaitu 31,971 dan 31,286 detik. Oleh karena itu, Katalon tidak dapat mendeteksi objek. Alasannya adalah pada Katalon tidak menyediakan slide sehingga layar tidak dapat digerakkan, dengan kata lain tangkap layar pada Device View bersifat statis. Karena itu, cara lain untuk dapat menjalankan sistem adalah dengan menggerakkan layar sentuh pada smartphone yang terkoneksi pada Katalon.

Selain kegagalan yang dijelaskan sebelumnya, ada hal yang ternyata perlu diperhatikan bahwa walaupun objek suara dikatakan sukses, pada saat berpindah halaman layar suara tetap berjalan sampai selesai. Bilamana pengguna mengaktifkan tombol suara yang lain, alhasil suara akan tumpang tindih. Contoh pada no. 17 tajwid/tanwin/ikhfa-suara dengan response time 33,027 bahwa respon objek suara tersebut sangat lama karena mempunyai ukuran memori yang cukup besar. Sehingga perlu dilakukan program control untuk mengendalikan objek suara agar saat berpindah halaman layar, suara tersebut dapat berhenti. Sehingga dalam hal ini, perlu juga dilakukan White Box Testing untuk menganalisa instruksi-instruksi yang dilakukan didalam pemrograman.

Berdasarkan analisa-analisa diatas, Katalon masih ada kekurangannya yaitu untuk dapat melakukan pengujian, perangkat asli tetap harus diaktifkan dan digerakkan karena pengujiannya langsung melalui koneksi dari smartphone dengan menggunakan kabel USB. Walaupun saat merekam menggunakan tangkap layar dari Device View. Namun, secara garis besar fungsinya sebagai Automation Testing Tool sudah dapat terpenuhi.

\section{SIMPULAN}

Objek yang dilakukan pengujian diantaranya adalah Fitur About; Fitur Mahraj (Mahraj Rongga Mulut, Mahraj Tenggorokan, Mahraj Lidah, dan Mahraj Bibir); Fitur Tajwid yaitu Tanwin (Izhar. Idgham, Ikhfa, Iqlab), Mim Mati (Ikhfa Syafawi, Idgham Mislain, Izhar Syafawi); Hukum Mad (Mad Thobi'i, Mad Wajib Muttasii, Mad Jaiz Munfasil, Mad Arid Lisukun); Hukum Idgham (Idgham Mutamatsilain, Idgham Mutajanisain, Idgham Mutaqaribain); Qalqalah (Qalqalah Kubro, Qalqalah Sugro); serta yang terakhir Fitur Kuis. Selain itu, ada pula objek suara yang perlu diujikan. Aplikasi tajwid ketika diuji membutuhkan 326,128 detik atau rata-rata sekitar 26,128 detik sampai dengan 5 menit dengan 121 langkah pengujian. Dari 121 langkah tersebut, terdapat 3 kegagalan, antara lain tampilan layar tidak dapat menyesuaikan ketika dirubah ke dalam mode Landscape. Sehingga mengakibatkan tampilan aplikasi keluar dari tampilan layar smartphone, Katalon tidak dapat mendeteksi objek yaitu tajwid/tanwin/idghm-suara1 (31,971) dan tajwid/tanwin/idghm-suara2 (31,286). Alasannya adalah pada Katalon tidak menyediakan slide sehingga layar tidak dapat digerakkan atau dengan kata lain tangkap layar pada Device View bersifat statis. Terdapat objek suara tetap berjalan sampai selesai walaupun sudah berpindah halaman layar. Bilamana mengaktifkan tombol suara yang lain, alhasil suara akan tumpang tindih. Penyebabnya dikarenakan mempunyai ukuran memori yang cukup besar sehingga response time menjadi lebih lama. Hal ini perlu dilakukan pengujian White Box untuk menganalisa instruksi pemrograman di dalam aplikasi. Berdasarkan analisa, dapat disimpulkan bahwa Katalon masih ada kekurangannya yaitu untuk dapat melakukan pengujian, perangkat asli tetap harus diaktifkan dan digerakkan karena pengujiannya tergantung dari koneksi smartphone. 
Walaupun saat merekam menggunakan Device View. Namun, fungsinya sebagai Automation Testing Tool sudah dapat terpenuhi.

\section{DAFTAR PUSTAKA}

[1] N. F. Azhar and S. Rochimah, "Memprediksi Waktu Memperbaiki Bug dari Laporan Bug Menggunakan Klasifikasi Random Forest," J. Sist. Dan Inform., vol. 11, no. 1, pp. 156-164, 2016.

[2] N. Kustian, "PENGGUNAAN MODEL WATERFALL DALAM PEMBUATAN APLIKASI PEMESANAN TIKET BUS," STRING (Satuan Tulisan Ris. dan Inov. Teknol., vol. 4, no. 1, pp. 94104, 2019.

[3] M. K. MZ, "Pengujian perangkat Lunak metode Black box berbasis partitions pada aplikasi sistem informasi di sekolah," J. Mikrotik, vol. 6, no. 3, pp. 2-16, 2016.

[4] K. Saravanan and E. P. C. Prasad, "Open Source Software Test Automation Tools: A Competitive Necessity," Sch. Int. J. Manag. Dev. ISSN 2394-3378, vol. 3, no. 6, pp. 103-110, 2016.
[5] W. N. Cholifah, Y. Yulianingsih, and S. M. Sagita, "Pengujian Black Box Testing pada Aplikasi Action \& Strategy Berbasis Android dengan Teknologi Phonegap," STRING (Satuan Tulisan Ris. dan Inov. Teknol., vol. 3, no. 2, pp. 206-210, 2018.

[6] M. M. Muhtadi, M. D. Friyadi, and A. Rahmani, "Analisis GUI Testing pada Aplikasi E-Commerce menggunakan Katalon," Pros. Ind. Res. Work. Natl. Semin., vol. 10, no. 1, pp. 1387-1393, 2019.

[7] D. Kusumawati, "Perancangan Aplikasi Pengenalan Cara Membaca Tajwid Menggunakan Android Studio Dengan Metode SDLC," Universitas Indraprasta PGRI, 2018.

[8] Katalon Team, "Android setup on Windows | Katalon Docs." [Online]. Available:

https://docs.katalon.com/katalonstudio/videos/android_setup_windo ws.html. [Accessed: 23-Nov-2019].

[9] Katalon Team, "Record Mobile Utility | Katalon Docs." [Online]. Available:

https://docs.katalon.com/katalonstudio/docs/record-mobileutility.html. [Accessed: 24-Nov2019]. 